\title{
A alimentação na dieta hipocrática
}

\author{
Henrique F. CAirus \\ Julieta Alsina \\ Universidade Federal do Rio de Janeiro
}

Brasil

Resumo. O presente artigo trata das relações entre o tratado Da dieta, do Corpus hippocraticum, e alguns discursos e ideias a ele coevos, com o objetivo de apontar sua intensa inserção nos jogos discursivos e no trânsito de saberes que o cercava. A partir de uma apresentação do tratado e do destaque dado ao seu longo trecho dedicado à alimentação, o artigo percorre seus vínculos intertextuais.

Palavras-Chave. Dieta hipocrática, corpus hippocraticum, medicina na Antiguidade, alimentação na Antiguidade Clássica, ciência antiga.

\section{Introdução: dieta, dieta alimentar e o catálogo dos alimentos no Da dieta}

O que os gregos antigos chamavam de dieta é o modo de vida que se deve deliberadamente seguir. No sentido lato, a palavra Síaıta carac-

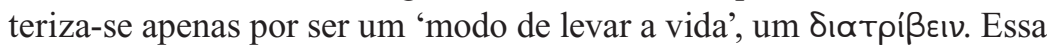
concepção é corrente em textos de autores antigos ${ }^{1}$ e mesmo em algumas passagens do próprio Corpus hippocraticum, mas não se percebe nela o sentido que direciona a dieta médica. Esse sentido é o de o modo de vida que se deve seguir regrado por um único fim: a saúde. Essa dieta mais ampla caracteriza-se apenas por ser descritiva, enquanto que a dieta médica diferencia-se pelo seu caráter normativo e prescritivo.

O sentido da palavra Síaıт no Corpus hippocraticum, apesar de traduzida pela tradição por 'dieta' ou por 'regime', compreende não só a alimentação, mas também as atividades físicas, os horários e os costumes específicos que impliquem em determinado fim, que, no campo da medicina,

Email: hcairus@ufrj.br e julieta.alsina@gmail.com

Departamento de Letras Clássicas da UFRJ. Membros do Grupo de Pesquisa PROAERA - Programa de Altos Estudos em Representações da Antiguidade - da UFRJ.

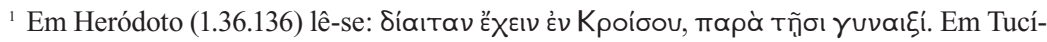

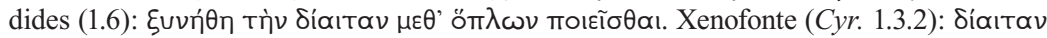

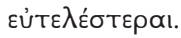


podem contemplar a manutenção ou a recuperação da saúde. Essa dieta, a da medicina, revela-se uma intervenção humana, um ato que se opera no

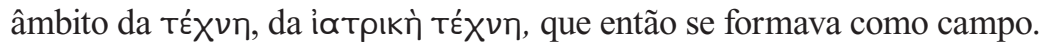

Adotamos, pois, a tradução de Síaıt a por "dieta" e não por "regime", levando em consideração o uso e o comprometimento semântico dos vocábulos nas línguas modernas. Além da preferência em conservar o termo grego, utilizar a palavra "regime" implicaria desconsiderar seus usos no vernáculo, quase sempre relacionados ao campo político.

$\mathrm{O}$ registro mais antigo da palavra Síaıta ligada especificamente à alimentação no Corpus hippocraticum encontra-se em um de seus mais célebres tratados, o Da medicina antiga. Ali também é pela primeira vez delineada uma concepção de dieta ligada à saúde, e, por conseguinte, de certa forma, uma concepção de que o homem se diferencia dos animais pelo comer. De fato, no tratado Da medicina antiga (7), lê-se:

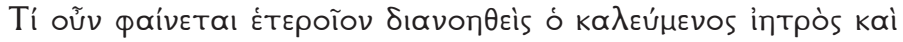

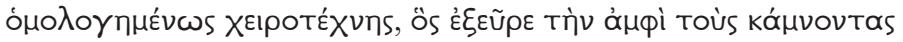

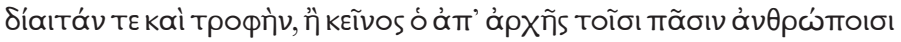

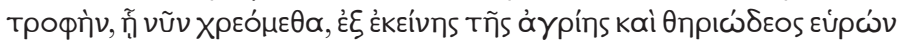

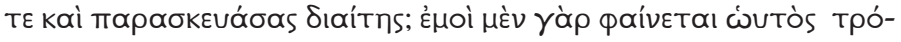

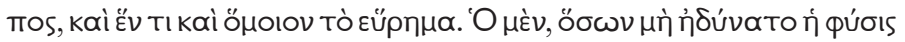

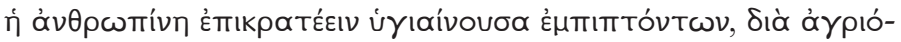

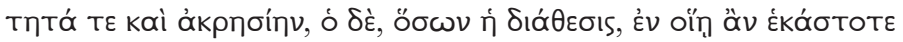

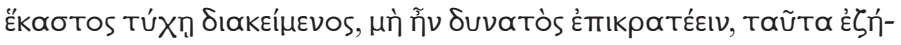

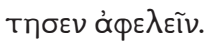

Qual é, então, a diferença de intenção entre aquele que chamamos médico e reconhecemos como praticante, que descobriu a dieta e a nutrição para os doentes, e aquele que por primeira vez descobriu e elaborou para todos os homens a alimentação que agora tomamos, diferente daquela outra dieta selvagem e própria dos animais? Pareceme, pois, que o modo é o mesmo, e único e idêntico o descobrimento. Ambos pretenderam o mesmo: um tentou suprimir os alimentos que uma natureza sã não poderia assimilar, pela sua brutalidade e estado puro, e o outro os que um homem não poderia suportar, a causa do estado de saúde em que por acidente se encontra.

$\mathrm{Na}$ doutrina dos escritos hipocráticos de Cós, a dieta é constituída por cinco componentes principais: a alimentação, os exercícios, a atividade profissional (o que implica em distinções sociais), o entorno geográfico e climático, e inclui também as atividades políticas da cidade em que o indivíduo vive; devia considerar a sua compleição física, a sua idade e sexo. 
O médico hipocrático devia levar em consideração os seus hábitos, como o sono, os sonhos, ou a frequência das atividades sexuais. Era importante, pois, verificar o meio, a região em que habitava, a posição da casa (sobretudo em relação aos ventos e ao sol), os alimentos que o paciente tinha à sua disposição; enfim, a sua Síaıt đ regular, para adequá-la a uma dieta de acordo em prol de uma saúde fundamentada na ideia de equilíbrio.

O médico hipocrático considerava todos esses elementos, ao formular a prescrição de uma dieta; mas, visto que mudar a residência do paciente, a profissão, ou as leis da sua cidade eram ações que pouco dependiam da participação do médico, sua atuação limitava-se à alimentação, aos exercícios e à prescrição de medicamentos, que, de resto, variavam também de acordo com o grau de intervenção possível, que, frequentemente, era pautado pela saúde e pelo tipo de doença.

Jacques Jouanna ${ }^{2}$ assim resume o tratado hipocrático Da Dieta (Пєрі Sıaítns, De Victu):

O tratado hipocrático Da dieta se divide em 4 livros. No primeiro, o autor dedica seus parágrafos a expor sua cosmologia, uma vez que considera que é essencial para prescrever uma dieta conhecer a natureza do homem. O homem, como os outros seres vivos, é constituído de duas substâncias primordiais, o fogo e a água, indissociáveis e complementarias. $\mathrm{O}$ fogo, quente e seco, tem por propriedade mover; a água, fria e úmida, tem por propriedade nutrir, mas as mudanças se operam entre esses dois elementos a partir das misturas, o que explica a diversidade dos seres vivos. O nascimento é a reunião desses elementos, e a morte, a separação. $\mathrm{O}$ autor trata em seguida da formação da natureza humana numa longa exposição de embriogênese. Expõe notadamente como o fogo organiza o embrião à imitação do universo ao criar três circuitos no interior do corpo, que são a imagem das revoluções da lua, do sol e dos astros (caps. 9-10). Tal organização da phýsis humana é imitada pela tékhne (caps. 11-24). O autor explica a formação do embrião macho ou fêmea (pela reunião de duas sementes vindas respectivamente do homem e da mulher), dos gêmeos e a superfetação (caps. 25-31). Expõe os diferentes tipos de constituições corporais e de inteligência de acordo com as variedades de mistura de água e fogo (caps. 32-36)

O livro II é essencialmente um catalogo das propriedades naturais e artificiais dos elementos da dieta (alimentos, bebidas e exercícios); é o mais desenvolvido catálogo da Coleção. Está precedido de dois capítulos sobre a influência dos lugares e dos ventos.

O terceiro livro (caps. 67-85 nas edições; cap. 67 até o fim em Galeno e em outros manuscritos antigos) trata de uma dieta propriamente

${ }^{2}$ Hippocrate, Paris, Fayard, 1992, p. 557. 
dita. O ideal, segundo o autor, seria chegar a um equilíbrio exato entre alimentos e exercícios. Mas as demasiadas variantes muitas vezes impedem a realização de tal equilíbrio. $\mathrm{O}$ autor distingue dois públicos: os que trabalham e não podem ocupar-se da sua saúde, e aqueles que dispõem de ócio para pensar na sua saúde. A respeito dos primeiros, expõe uma dieta anual em função de cada estação; mas se refere sobretudo a uma elite e revela o que ele acredita ser a sua descoberta. Tal descoberta é um prognóstico prévio à doença e um diagnóstico da causa que acarreta sempre um desequilíbrio entre os alimentos e os exercícios. Ilustra sua descoberta por uma série de casos (cap. 70 85): seis para os alimentos sobre os exercícios e oito para os exercícios sobre os alimentos.

O quarto livro (cap. 86-93, apenas nas edições modernas) completa a exposição do diagnóstico prévio para a utilização dos sonhos. $\mathrm{O}$ autor distingue duas categorias de sonhos: os divinos, que anunciam fortuna ou infortúnio e sejam úteis aos intérpretes de sonhos; os sonhos em que a alma informa sobre o estado do corpo e que são competência dos médicos. A respeito da segunda categoria, o autor estabelece um prognóstico e um diagnóstico sobre a saúde e a doença em função da diferentes visões. Aconselha eventualmente um tratamento. É nesse quadro que ele recomenda preces aos deuses.

Interessa-nos aqui de modo especial a configuração do discurso acerca da alimentação no tratado hipocrático Da dieta. Por isso, voltamos nossa atenção para o catálogo de alimentos encontrado no livro II, que e abrange principalmente os capítulos de 39 a 56 Littré $^{3}$, do tratado Da dieta. São esses, de fato, os capítulos dedicados exclusivamente à ali-

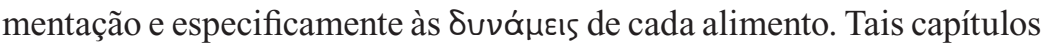
arrolam não somente os alimentos a serem ingeridos em tais ou quais circunstâncias médicas, mas incluem também uma série de variáveis quanto ao preparo e as ocasiões de ingestão desses alimentos, com uma lógica bastante peculiar que se deve acompanhar e mesmo interpretar. Inserese esse escrito numa tradição de catalogação de alimentos da qual restou vago resquício, mas que o testemunho do próprio tratado Da dieta faz crer que gozavam de certa popularidade na segunda metade do século $\mathrm{V}^{4}$.

\footnotetext{
${ }^{3}$ É. LitrRé, Oeuvres Complètes d'Hippocrate, v. 6, Paris, Baillière, 1849; esses capítulos correspondem aproximadamente ao livro II da edição de W.H.S. JonEs (Hippocrates, v. 4, Cambridge and London, Harvard University Press, 1931), embora tal divisão inclua os capítulos 37 a 60.

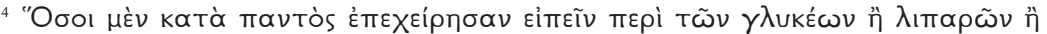

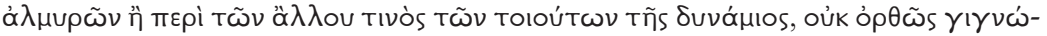

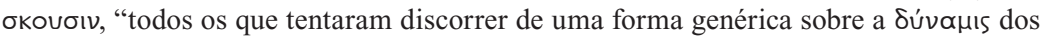


Esta tradição à qual o autor do tratado se refere como incompleta ${ }^{5}$, ganha, através da sua inserção na tradição hipocrática, o caráter de prescrição com vistas à saúde sem um caráter estritamente moral ${ }^{6}$, como se diz terem sido os catálogos pitagóricos de alimentos, propondo-se ele mesmo, bem ao modo de outros tratados hipocráticos ${ }^{7}$, a fazer uma síntese superior aos seus precedentes (Hp. Vict. 1 Littré):

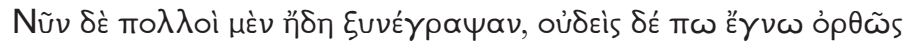

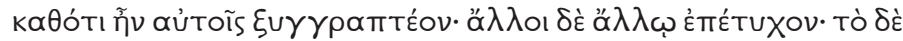

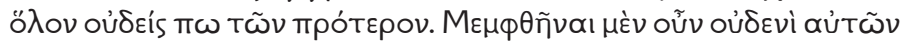

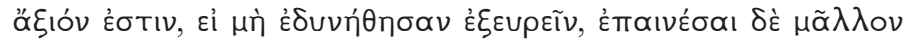

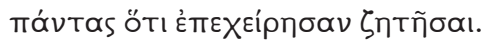

Muitos já escreveram (sobre esses temas), mas ninguém ainda soube com precisão como deveria escrever sobre eles. Alguns acertaram num ponto, outros em outro; mas no conjunto ainda nenhum dos meus predecessores o fez. Entretanto, não é justo condená-los por não haver podido completar suas descobertas, mas é preciso elogiálos por haver empreendido tal investigação.

Carlos García Gual ${ }^{8}$ assinala o fato de o nosso autor insistir na multiplicidade de escritos sobre o mesmo tema, a partir do uso repetido do

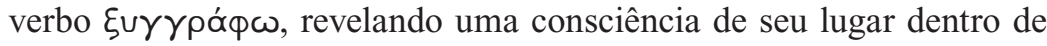
uma tradição da dietética, e dentro das próprias práticas da medicina

doces ou dos (alimentos) gordurosos ou salgados ou de qualquer outro (alimento) assim, não os conhecem corretamente" (39 Littré). Observe-se aqui o uso do termo öఠol, que sugere haver uma certa quantidade de discursos em forma de catálogos alimentícios, mas, ao menos segundo o autor estudado, esses discursos eram katà та vтòs, genéricos. O uso desta expressão insinua que, ao contrário daquele do Da dieta, os demais catálogos não contemplam um fim específico, e, por isso, não seriam da ordem da TÉxvๆ.

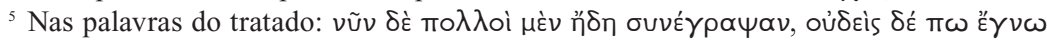

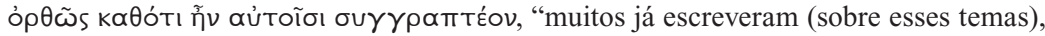
mas ninguém ainda soube com precisão como deveria escrever sobre eles".

${ }^{6}$ Registre-se aqui que uma perspectiva tradicional, que tem por grande baluarte o polígrafo Laín Entralgo, caminha na direção diversa à que propomos, e encontra feições morais e até religiosas nas dietas pré-hipocráticas, conferindo, assim, como sói acontecer a esse tipo de abordagem, um papel laicizador à escola hipocrática. Tal abordagem, além de estar comprometida com uma perspectiva evolucionista, nega ao corpus hippocraticum seu aspecto dialogístico em relação à cultura que o cerca e que, em certa medida, o engendra. Procuramos, contudo, não negligenciar o papel que os estudos dessa ordem desempenharam na construção da imagem de um Hipócrates pai não somente da medicina, mas de toda a ciência, como tanto queria Émile Littré.

${ }^{7}$ Em especial, o Da medicina antiga.

${ }^{8}$ Tratados hipocráticos, v. 8, Madrid, Gredos, 1986, p. 23. 
hipocrática, que se consolidava naquela época principalmente através da transmissão escrita.

Galeno (6.473K) atesta que este catálogo circulava em edições independentes do restante do tratado, algumas começando no cap. 37 do tratado, outras no 39. Do ponto de vista de Galeno', a autoria do livro I não reflete o pensamento de Hipócrates, porquanto se tratasse de um 'pastiche' filosófico, e, não obstante, atribui, com toda a convicção, o livro II à escola hipocrática, porém, como sói, não é claro quanto aos critérios, que parecem sempre comprometidos com uma idealização de um Hipócrates baluarte do campo da medicina.

A hipótese levantada de que o livro I seja posterior ao catálogo tornase mais consistente na medida em que há, de fato, uma certa diferença entre os estilos de escrita e de objetivos de ambos os livros, sendo estes capítulos de ordem prescritiva e os que os antecedem, de ordem epidíctica $^{10}$ e teórica. No catálogo, contudo, é possível entrever uma postura condizente com os physiológoi, especialmente na dualidade fogo-água, que se reflete nos pares antitéticos frio-quente e úmido-seco, pares que, de resto, aparecem em outros tratados hipocráticos, entre os quais vale citar, por sua importância no todo da Coleção hipocrática, o Da natureza do homem, o Da medicina antiga, e o Dos ares, águas e lugares.

Considera-se, assim, ter sido o catálogo de nosso autor um dos mais importantes catálogos de alimentos da Antiguidade, não só pela sua leitura e apropriação no campo da medicina e pela constituição de uma 'verdadeira' ${ }^{11}$ dietética como se a conheceu até o século XIX ${ }^{12}$, uma vez que, de todos os supostos catálogos dietéticos alimentares, foi precisamente este o único sobrevivente. Por essa razão, o corpus eleito será, cremos, capaz de fornecer-nos dados, que, ainda que escassos, poderão suprir as necessidades do estudo.

\footnotetext{
${ }^{9}$ Vale aqui lembrar que Galeno atribuía a autoria dos textos hipocráticos por um interessante critério de mérito (ver H. CAIRus, O vocabulário fisiológico do Tratado hipocrático Da natureza do homem, Dissertação de Mestrado, Rio de Janeiro, UFRJ, 1994, p. 28-9). ${ }^{10} \mathrm{O}$ genêro epidítico, ou a epídeixis, parece referir-se a preleções orais, ao modo da apódeixis de Heródoto.

${ }^{11}$ R. Joly (Le niveau de la science hippocratique, Paris, Les Belles Lettres, 1967, p. 122) mostra com riqueza argumentativa a importância dessa dieta 'verdadeira'.

${ }^{12} \mathrm{O}$ século XIX produz uma passagem do Corpus hippocraticum da medicina para a história da medicina. Ver H. CAIRUs, Os limites do sagrado na nosologia hipocrática, Tese de Doutorado, Rio de Janeiro, UFRJ, 1999, p. 5-7; H.F. CAIRus, 'O Corpus hippocraticum', in H.F. Cairus e W.A. Ribeiro JR., Textos hipocráticos: o doente, o médico e a doença, Rio de Janeiro, Fiocruz, 2005, p. 25-38.
} 


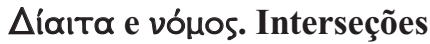

A dieta proposta pelo tratado é cerceada por um vónos. Seus limites são claramente os desse costume normatizador, que, para os gregos configurava a expressão máxima de sua cultura ${ }^{13}$. Tanto a dieta - aqui compreendida lato sensu - equivocada quanto a dieta médica, fruto da

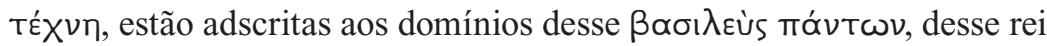
de todas as coisas, conforme Heródoto dizia ter Píndaro definido o vónos. Tal limite dessa prática médica e a sua necessária submissão à prática so-

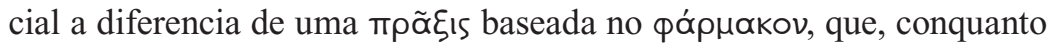

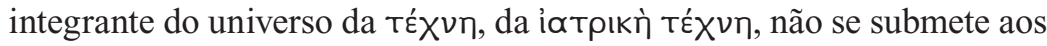
domínios do vómos social pré-existente, mas à imposição de uma espécie de vómos da doença, de um vó de ơvouía. O qápuakov, ao contrário da dieta, gera um vómos próprio, onde uma nova ordem proposta pelo discurso médico (e seus afluentes) colocaram a doença, tirando-o de uma selvageria que uma certa retórica hegemônica especialmente na Atenas clássica assimilou à barbárie.

Para além da literatura hipocrática, a dieta era compreendida como uma inovação, associada a uma nova ordem políade. Aristófanes, na comédia As nuvens (960-84), no ợ ćv entre o Raciocínio Justo e o Raciocínio Injusto, menciona as práticas dietéticas, referidas, em significante metafórico, pelo Raciocínio Justo, que, por sua vez, opunha-se à atmosfera de novidade da pólis. Trata-se de uma inversão que parece ressaltar o contraste entre a dieta alimentar característica da proposta de uma nova ordem e os costumes pudicos que o Raciocínio Justo reivindicava. Defendemos que a ideia era usar as armas do rival retórico, transformandoas em metáforas que trazem à cena uma saudosa ${ }^{14}$ pudicícia relacionada às manifestações públicas dos desejos sexuais. De qualquer maneira, a dieta é explicitamente citada, numa referência à prescrição (e interdição) dos rabanetes - que, por sua vez, são imagens evidentemente fálicas -,

${ }^{13}$ Como mera ilustração dessa assertiva, pode-se citar o épos pindárico mencionado por

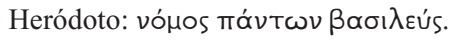

${ }^{14}$ No verso 984, o Raciocínio Injusto, indiferente à alusão à dieta, replicará: ápx ã̃ó $\gamma \varepsilon$

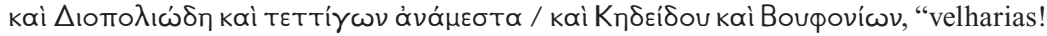
assim como as Diopolias (i.e., as festividades de Zeus padroeiro), plenas de cigarras, / de Cidides (i.e., dos ditirambos antigos de Cidides) e de bufonias (i.e., de sacrifícios de bois, em pleno desuso)". Seguimos aqui a sugestão do LSJ e interpretamos a expressão "plenas de cigarras" como "plenas de prendedores de cabelo antiquados". Tais prendedores foram usados nas Guerras Greco-Pérsicas, conforme atesta Tucídides em sua Arqueologia (1.6). A réplica insiste no tópos do novo contra o antigo, mas sua posição evidencia a postura saudosista do adversário, o Raciocínio Justo. 
dando razões para se pensar em uma certa popularidade desse tratado, e, até mesmo, numa possível resistência a ele (973-83):

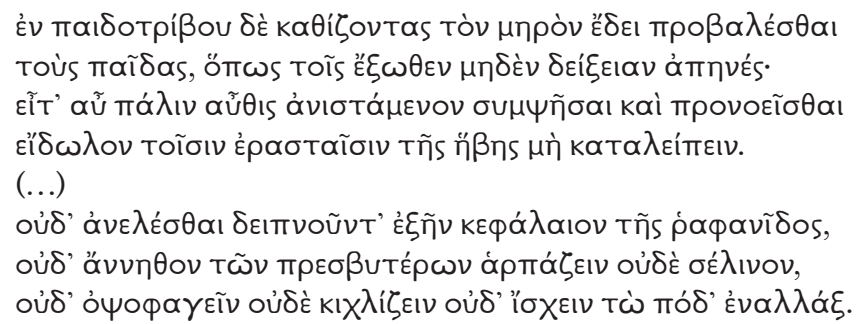

E nas aulas de ginástica, os jovens deviam sentar-se com as pernas esticadas, de modo que aos de fora nada deixassem ver; e depois ao se levantarem novamente deviam todos juntos varrer o chão e evitar mostrar uma imagem de virilidade aos admiradores.

(...) não era permitido ao jantar (comer) a cabeça do rabanete, nem pegar no aneto nem no aipo dos mais velhos, nem comer peixes nem gargalhar nem manter as pernas cruzadas.

E ainda nos versos 999-1000 há uma jocosa referência a Hipócrates, filho de Arrifron e, portanto, primo de Péricles, cujos três filhos eram conhecidos pela sua proverbial estupidez. A homonímia com o célebre médico parece reforçar a hipótese da referência à dieta em versos não anteriores e próximos. Nesses versos, o Raciocínio Injusto inverte o jogo, acusando o adversário de unir-se a quem deveria ser identificado como associado às ideias novas:

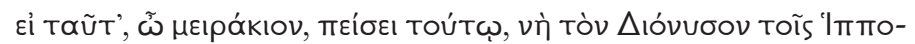

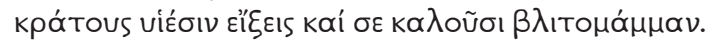

Se dessa forma, menininho, com isso sofres, por Dioniso, parecerte-ás com os filhotes ${ }^{15}$ de Hipócrates e chamar-te-ão de grande mamador de tetas ${ }^{16}$.

${ }^{15}$ Jogo de palavras intraduzível, uma vez que úí́oıv (dat. pl. de viós) é quase homófono de ưoív (dat. pl. de ũs, "porco", animal que os gregos frequentemente associavam à estupidez (ver Ar. Pax 928; Eq. 986).

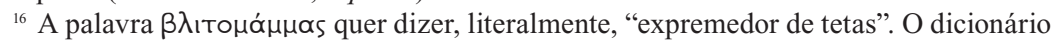
de Anatole Bailly apresenta a tradução "grande tolo" para esse vocábulo, o que, a nosso ver, tem uma carga pejorativa muito menor do que a que o texto sugere. Nossa hipótese é a de que, nessa passagem, o Raciocínio Injusto faz ressoar a ideia de que seguir Hipócrates (mamar-lhe às tetas) é uma grande estultícia pueril, fazendo ecoar esse nome que, ao mesmo tempo é ligado à família de Péricles e ao célebre médico, valendo-se, assim, de um sofisticado recurso que, ao mesmo tempo, traz a lembrança do emblemático nome de Hipócrates e coloca-o ao lado de seu adversário, sugerindo uma identificação entre o Raciocínio Injusto e uma visão ingênua daquilo que era tomado como novidade. 
Nossa hipótese parace ir de encontro com a postura de Jouanna, que tece uma observação na qual invoca outros testemunhos ${ }^{17}$ :

Além dos registros de cuidados que precisam de uma terapêutica de intervenção (medicamentos catárticos, incisões, cauterização), o médico dispunha de um registro para se opor à doença: a dieta do doente.

Assim, a terapêutica de intervenção pertence à medicina tradicional, a arte da dieta passa da antiguidade para ser uma conquista mais recente. O testemunho mais célebre a esse respeito é o de Platão, na República. À medicina farmacológica da época de Homero ele opõe a medicina dietética dos seus contemporâneos. Platão não via nessa evolução um progresso. Essa nova medicina, que constrangia os doentes a uma observação de um longo regime, os desviava, segundo ele, de cumprir seus deveres de cidadãos. Mas, vista do lado dos médicos, tal evolução apareceu como um progresso. O autor hipocrático que expôs a dieta para as doenças agudas critica o caráter farmacológico da terapêutica dos autores das sentenças cnídias e reprocha os antigos em geral de não haver dito nada válido sobre a dieta. Uma terapêutica que não se contenta com um catártico, com uma incisão ou com uma cauterização para evacuar o mal, mas que adapta a dieta do doente à doença e à sua evolução, eis algo que passou por uma novidade da medicina do fim do V e início do IV, já mesmo aos olhos dos contemporâneos.

Trata-se aqui, portanto, de uma pretensa parte do grande mosaico do discurso civilizatório no qual os gregos da pólis clássica, em vários momentos, se empenhavam e ao qual aprenderam a opor uma ancestralidade que Tucídides (1.6) ${ }^{18}$ chegou a identificar com os mesmos bárbaros retoricamente irmanados em uma não (ou sub) cultura, à despeito do trabalho de Heródoto e do autor do tratado Ares, águas e lugares ${ }^{19}$. Consiste pressuposto fundamental desse projeto civilizador a abrangência do conceito de vónos, que merece ser repensado para além da alçada do binômio, já clássico na teoria, formado pelos conceitos de natureza e cultura. O vómos, enquanto costume gerador de norma, interessa-nos

17 1992, p. 232-3.

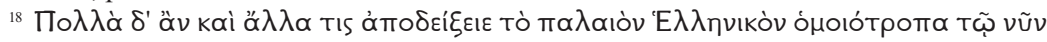

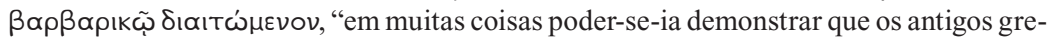
gos tinham uma dieta semelhante ao dos hodiernos bárbaros". Observe-se, aqui, o uso

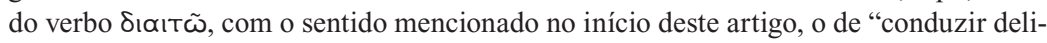
beradamente a vida".

${ }^{19}$ A esse respeito, ver H.F. CAIRUs, Asiáticos diferentes entre si: o Corpus hippocraticum e a alteridade interna, Rio de Janeiro, PROAERA, 2003, disponível em http://www.letras. ufrj.br/proaera/ alteridadeinterna.pdf. 
para entender o procedimento hipocrático, uma vez que as operações dietéticas eram circunscritas a esse limite, a partir do qual sua prescrição dialogava com a qúoıs.

A dieta, portanto, configura-se como um instrumento desse vómos com o qual o homem, e especialmente o médico, através da i̊трıкท̀ тย́-

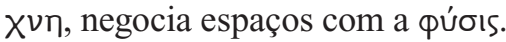

No plano discursivo, stricto sensu, postulamos haver um escopo de - a partir do projeto de legitimação de um campo, assim como no estudo do que chamamos de práticas alimentares - estabelecer o saber e a prática médica dentro do lugar social que ela pretendia ocupar.

\section{A teia discursiva do catálogo dos alimentos}

Para lidar com temas concernentes ao estudo do texto enquanto fonte, assim como o desenvolvimento da tradução proposta, utilizamos as perspectivas de alguns autores que se dedicam ou que se dedicaram ao mesmo corpus ou a corpora afins, tais como as de Jacques Jouanna e Carlos García Gual. Esses autores, dentre os especialistas que se dedicaram à Coleção hipocrática, destacam-se por apresentar leituras 'inovadoras' em relação ao tratamento de conceitos tomados como 'problemáticos' no estudo do Corpus hippocraticum, especialmente frente às perspectivas de Robert Joly e de W.H.S. Jones, representantes de uma postura tradicional, que, embora apurada, ainda se coloca entre o $\mu$ ũ 0 os e o $\lambda$ óyos.

Pela escolha de uma linguagem declaradamente 'atualizada' em relação às outras traduções deste tratado, na sua versão ao espanhol do $D a$ dieta, a abordagem de Carlos García Gual, Catedrático da Universidade Complutense de Madri e diretor da coleção de clássicos da Editora Gredos, harmoniza um fino tratamento filológico à obra em questão a um cuidado com a linguagem empregada em sua tradução, com uma peculiar preocupação - declarada - de varrer todo rasgo de positivismo. Esse tipo de estudo é interessante não apenas no que ele tem a oferecer em termos de dados, mas, principalmente, pelo tipo de leitura apresentada, que revela uma tentativa de afastar a imagem 'racionalista' do 'pai da medicina' de um público-leitor enraizado na imagem de um Hipócrates à moda de Littré.

Jacques Jouanna alia uma visão de cunho histórico, fundamentada intertextualmente numa erudição filológica que não se justifica por si, como na sobrevida germânica da tradição ecdótica do século XIX. Sua perspectiva teórica historicizante não teme o risco de usar todo o pesado arsenal filológico criado por essa tradição e serve-se dele para, a partir de um sólido e aprofundado conhecimento das relações intertextuais (que devidamente 
perpassam as considerações sobre transmissão e práticas performáticas coevas à produção textual), oferecer ao leitor especializado e mesmo ao leitor leigo uma abordagem onde o corpus de análise assume um lugar na história delineado por si, por sua transmissão, por sua recepção e por seus envolvimentos performáticos ${ }^{20}$. É de Jouanna o estudo ${ }^{21}$ mais aprofundado sobre a relação entre as escolas de Cós e de Cnido. Tal estudo inevitavelmente perpassa o tema da oposição entre a primazias do фápuákov e a da Síaıт . Jouanna mostra como, no tratado cnídio Doenças II, a dieta figura ${ }^{22}$, mostrando que, as variáveis no tratamento dietético são um koıvóv entre as escolas de Cnido e de Cós ${ }^{23}$. O texto do Doenças II, no entanto, parece conter mais uma farmacologia alimentar do que uma dietética propriamente. Além disso, o tratado Doenças II apresenta os alimentos (sempre como

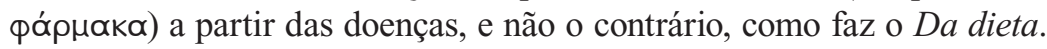

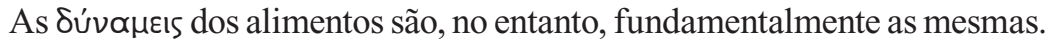

Os estudos de Jouanna, embora afortunados e ainda inigualados, ainda não nos oferecem o caminho definitivo na divisa entre as escolas de Cós e de Cnido no que tange especificamente ao tema da dieta, e abrir esse caminho continua um trabalho ainda por fazer. É certo, contudo, que o tema da dieta, se é caro à medicina hipocrática, é muito mais caro ainda àquela oriunda da chamada escola de Cós, nome sob o qual é conhecida a tradição que o tratado Da dieta integra em posição destacada.

A urdidura textual de certos tratados hipocráticos contam com uma argumentação que não pode prescindir do diálogo com as ideias que o cercavam, e tal arquitetura discursiva, por vezes com familiaridade com a retórica, apresenta uma rede de relações intertextuais cujo exame faz-se necessário. Frequentemente os proêmios dos tratados assinalam alguns (mas nunca todos os) seus interlocutores ideais.

É possível, pois, constituir-se um inventário da presença de ideias atribuídas a alguns pensadores pré-socráticos, especialmente aos pitagóricos, que ecoam em alguns dos tratados hipocráticos, e também em certas

\footnotetext{
${ }^{20}$ Note-se, aqui, que o tratado ao qual se dedica este artigo é uma epídexis ou, no dizer da taxonomia retórica, um discurso epidíctico.

${ }^{21}$ Hippocrate et l'école de Cnide: pour une archéologie de l'école de Cnide, Paris, Les Belles Lettres, 1974. Essa obra teve mais duas edições: uma em 2004, com o acréscimo de um capítulo, e outra em 2009, com a adição de um posfácio.

${ }^{22}$ A dieta é aplicada apenas àlgumas doenças, no fim do tratado. Especificamente, nos capítulos 66 a 74 (penúltimo), exctuando-se, o capítulo 67, que trata de uma doença no-

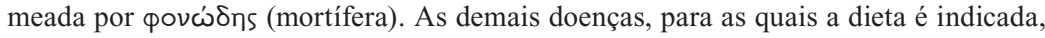
são: doença ressecante (66), doença lívida (68), doença de eructação (69), flegmasia (70), leucoflegmasia (71), ansiedade (72), doença negra (73), outra doença negra (74).

${ }_{23}$ JoUANnA, 1974, p. 458-9.
} 
passagens do tratado Da dieta, a partir de convergências de ideias, em geral provenientes de perspectivas cosmogônicas. A elaboração desse inventário, todavia, não pode perder de vista que houve e há uma certa fortuna crítica que superestimou a relação entre a medicina hipocrática e a filosofia dita pré-socrática. Entretanto, no caso específico da dietética, não se deve relevar a importância dos pitagóricos, tidos como os precursores desse campo.

Diógenes Laércio afirma que o discurso de Alcmeon é mais médico

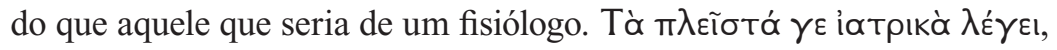
diz Diógenes Laércio (8.83). Mais do que isso, afirma que "ele parece ter sido o primeiro a escrever um discurso físico", ${ }^{24}$ opinião também compartilhada por Clemente de Alexandria (Strom. 1.78).

Écio, por outro lado, oferece um breve testemunho da teoria do médico ou fisiólogo de Crotona acerca da saúde, teoria que se verá presente em todos os tratados do Corpus hippocraticum (Aët. 5.14.1 = Alcmeon Fr. 4 DK):

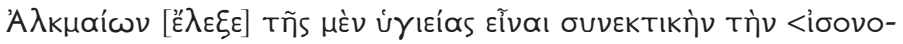

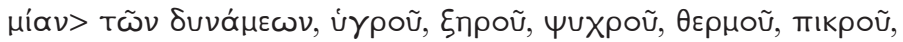

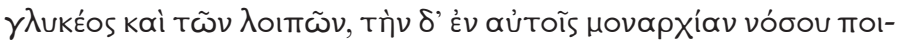

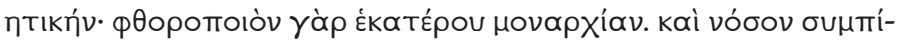

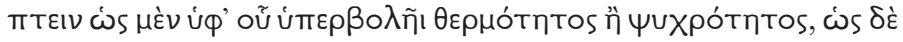

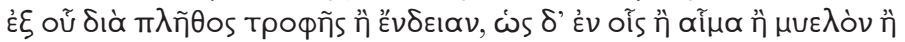

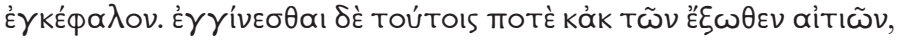

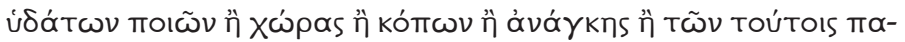

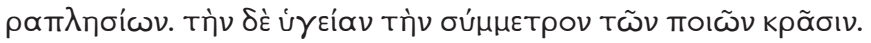

Alcmeon disse ser a constituição da saúde o equilíbrio das propriedades: do úmido, do seco, do frio, do quente, do amargo, do doce e dos restantes, e a monarquia entre eles produz doença, pois a monarquia de cada uma é o que causa destruição. Assim, a doença sobrevém por um lado quando há um excesso de calor ou de frio, ou de outras, quando devida à abundância ou à carência de um alimento, o que ocorre em partes como o sangue, a medula ou o cérebro. Essas partes podem ser também afetadas por causas externas, como certas qualidades de águas, certas regiões, pela fadiga ou por experimentar-se uma necessidade ou devido ao que lhes estiver perto. Mas ainda quanto à saúde, ela é a justa medida da mistura das qualidades.

Assim como pensara Anaximandro, para quem a tensão entre contrários resulta em uma $\delta i ́ k n ~(F r .1 \mathrm{DK})^{25}$ - já que a prevalência de uma

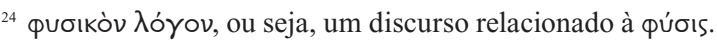

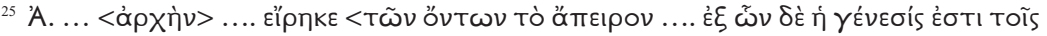

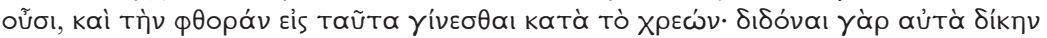

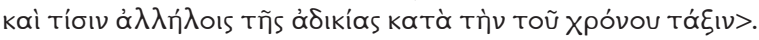


substância sobre outra é injustiça, áరııía -, Alcmeon leva essa teoria ao corpo e à compreensão da saúde como uma isonomia (ioovouía) das propriedades que a compõem, enquanto a doença se configura como a

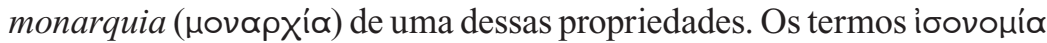

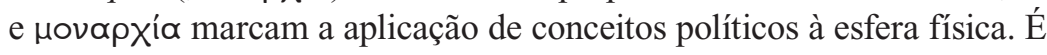

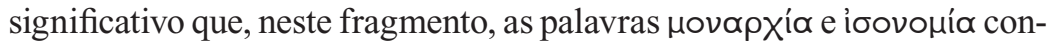
tém em si as raízes de ợxń e vónos, respectivamente, o que faz ressoar a inversão da concepção de pólis como um corpo, que viria a ser um tópos na historiografia de Tucídides ${ }^{26}$. A ação humana, motriz da organização

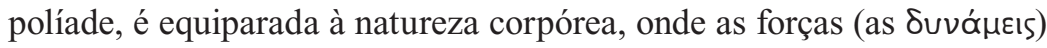
devem estar em equilíbrio, e esse equilíbrio é tanto o bem-estar da cidade quanto a própria saúde.

Nos séculos V e IV a.C., o princípio de Alcmeon, tradução fisiológica do $\mu \eta \delta \varepsilon \dot{v}$ ơy $\gamma v$, ganhou vulto através dos textos das escolas médicas de Cós e Cnido. Platão refere-se a esse princípio no Banquete, no discurso do

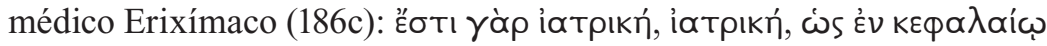

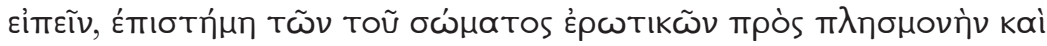

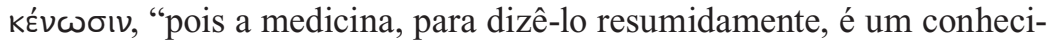
mento do que há de erótico no corpo, em relação à repleção e à vacuidade."

O binômio formado por vacuidade e repleção tem lugar de relevo na dietética, uma vez que codifica os efeitos das comidas e bebidas e da ginástica num movimento complementar de falta e excesso (Hp. Vict. 1.2):

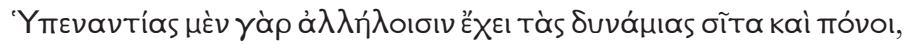

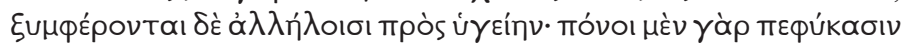

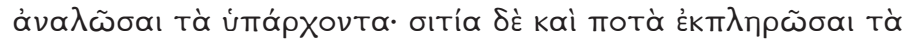

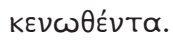

Pois os exercícios físicos e as comidas apresentam propriedades opostas entre si, mas se complementam com vistas à saúde. Porque os exercícios físicos produzem por natureza um gasto do acumulado, enquanto os alimentos e bebidas restauram o esvaziado.

Esse binômio, portanto, fundamenta a explicação dos processos fisiológicos básicos da dieta, que constituem o 'movimento alternado no

\footnotetext{
${ }^{26}$ Sobre a cidade como um corpo em Tucídides, pelo viés hipocrático, v. Helena MiRANDA Mollo, A influência do corpus hippocraticum na historiografia de Tucídides, Dissertação de Mestrado, Rio de Janeiro, UFRJ, 1994, e Andrea Coelho Farias Draeger, Para além do lógos: a peste de Atenas na obra de Tucídides, Dissertação de Mestrado, Rio de Janeiro, UFRJ, 2004.
} 
qual se baseia o funcionamento saudável do corpo ${ }^{27}$, de acordo com a proporção de ambos, exercícios e alimentos (Hp. Vict. 1.2):

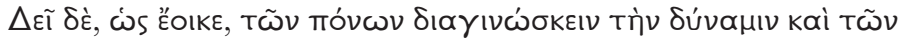

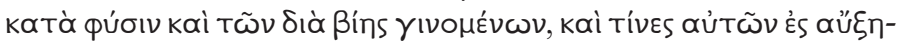

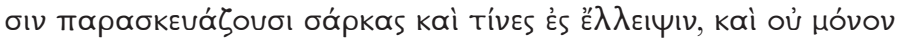

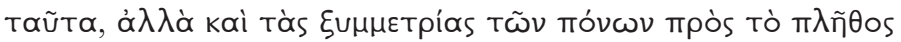

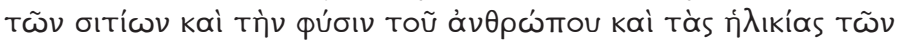

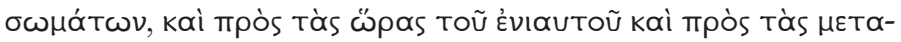

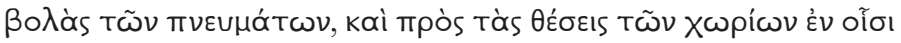

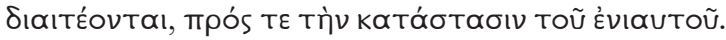

É preciso, como parece, discernir a propriedade dos exercícios, conhecendo-os tanto pela natureza quanto pela força, e alguns deles preparam as carnes para aumentá-las, e outros para diminuí-las, e não apenas essas coisas, mas também (conhecer) as simetrias dos exercícios em relação à repleção (que vem) dos alimentos; assim como (conhecer) a natureza do homem e as idades dos corpos, tanto em relação às estações do ano, quanto em relação às mudanças dos ares, as situações das regiões em que se habita e a ordem do ano.

O médico tratadista do livro I do Da dieta, num estilo semelhante ao de Arquelau - para quem 'a água por ação do quente quando se junta desce para a região mais baixa devido ao elemento ígneo, fazendo a terra, e no percurso, cria o ar' (D.L. 5.42) - afirma que (Hp. Vict. 1.3)

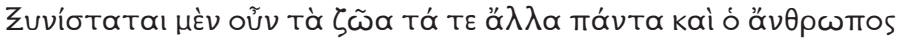

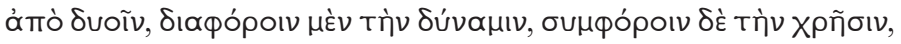

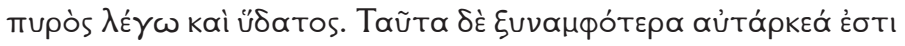

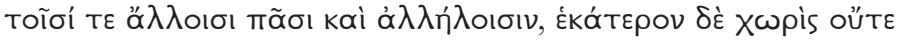

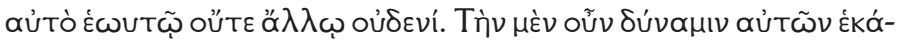

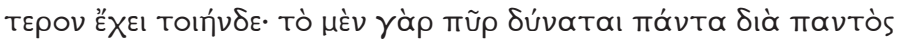

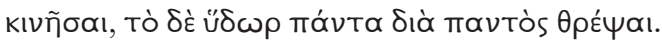

Os seres vivos, tanto o homem como todos os outros, estão constituídos por dois elementos, divergentes pela sua propriedade, convergentes pela sua utilidade: fogo e água. Ambos combinados são auto-suficientes frente a todos os outros e para si mesmos; mas cada um por si, separadamente, não é nada nem para si mesmo, nem para nenhum outro. Quanto à sua propriedade, cada um possui a seguinte: o fogo pode mover tudo por meio de tudo e a água, nutrir tudo a partir de tudo.

${ }^{27}$ Carlos García Gual, Tratados hipocráticos, v. 3, Madrid, Gredos, p. 22, nota 6. 
Os tratados do Corpus hippocraticum que apresentam uma parte polêmica - seja o Da medicina antiga, o Da doença sagrada, o Da natureza do homem, o Da arte ou o Da dieta - são especialmente interessantes para o estudo da relação entre a medicina grega e o mundo no qual ela estava inserida. Não é possível, entretanto, negligenciar-se os primeiros parágrafos do tratado Da natureza do homem, da lavra de Pólibo, genro e discípulo direto do próprio Hipócrates, quando se pretende averiguar a esfera de influência dos pensadores pré-socráticos, particularmente dos monistas (Hp. Nat. Hom. 1 Littré):

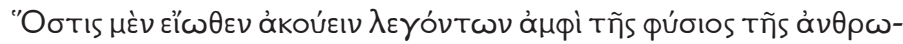

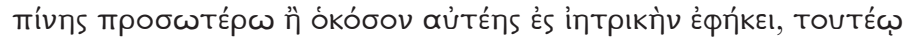

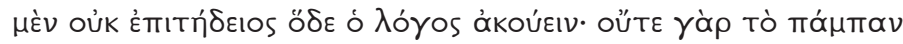

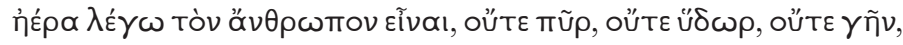

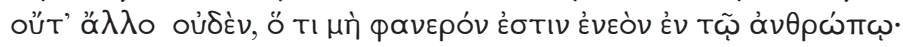

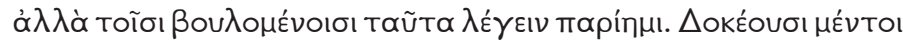

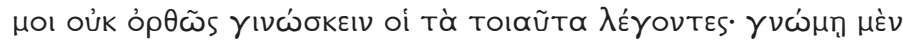

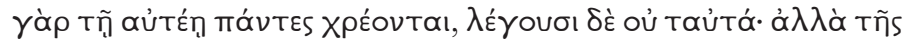

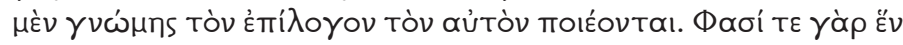

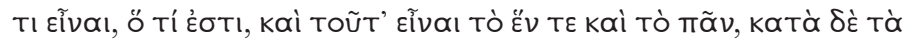

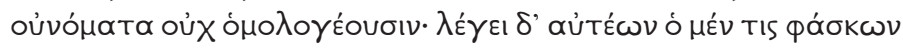

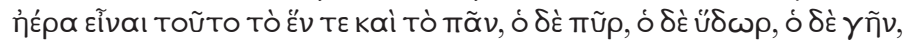

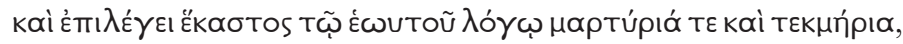

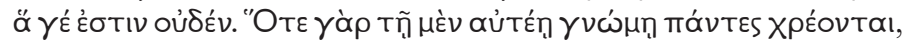

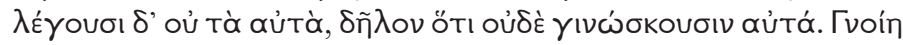

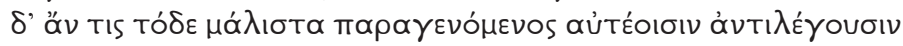

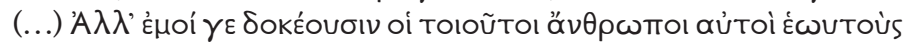

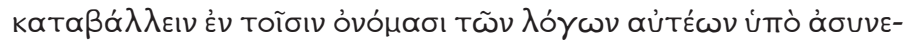
бíns, Tòv $\delta \varepsilon \dot{~ M E \lambda i ́ \sigma o o u ~ \lambda o ́ \gamma o v ~ o ́ p \theta o u ̃ v . ~}$

Quem costuma ouvir aqueles que falam sobre a natureza humana, além do que concerne à medicina, para ele, este discurso não é interessante de ser ouvido. Digo, pois, não ser o homem, por completo, nem ar nem fogo nem água nem terra nem nenhum outro elemento que não é manifesto no interior do próprio homem. Mas deixo de lado aqueles que querem falar tais coisas. Certamente não me parece que os que dizem tais coisas as conheçam perfeitamente. Usam todos o mesmo juízo, e não dizem as mesmas coisas; mas desse juízo eles chegam à mesma conclusão. Dizem, pois, ser uno algo que existe, e ser este uno o uno e o todo, mas não concordam sobre os nomes. Diz um deles ser o ar o uno e o todo; o outro ser o fogo; o outro, a água; o outro, a terra. Cada um acrescentando ao próprio discurso testemunhas e provas que nada são. Quando, pois, todos utilizam o mesmo juízo, mas não dizem as mesmas coisas, é evidente que não 
as conhecem. (...) Parece-me, porém, que estes homens derrubam-se a si mesmos nos termos dos seus discursos, por inabilidade, e restabelecem o discurso de Mélissos.

A tese da predominância dos humores numa determinada estação do ano tem, também, ligação com as ideias de Empédocles. Pólibo exemplifica a teoria lembrando como uma planta retira da terra aquilo que for mais de acordo com a sua natureza constitutiva. No fragmento $90 \mathrm{DK}$ de Empédocles podem-se notar os primeiros sinais dessa tese: $\omega_{\varsigma} \gamma \lambda$ UKù $\mu \varepsilon \dot{\nu}$

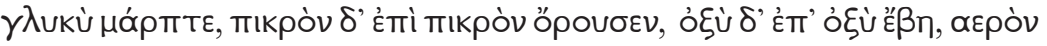
$\delta$ ' є̇тоХЕітто $\propto \propto п \rho \tilde{\iota}$ no fragmento: 'o doce atrai o doce; o amargo se enlaça no amargo; o acre encontrará o acre; o ardente arranca o ardente.'

Diferente de Empédocles, Anaxágoras de Clazómenas entende que a percepção não é dada pelos semelhantes, mas pelos contrários, concepção que é notada em muitos escritos hipocráticos, principalmente em algumas passagens do Da dieta e do Da arte. Teofrasto, no seu tratado Sobre a percepção diz sobre o filósofo de Clazómenas que (27-8)

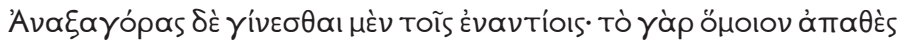

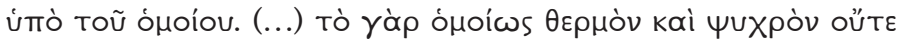

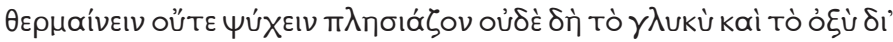

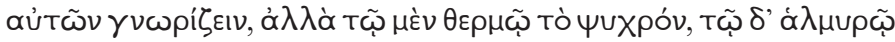

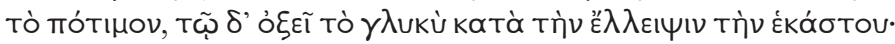

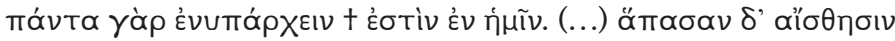

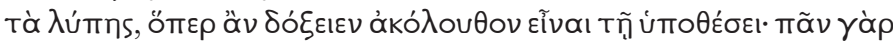

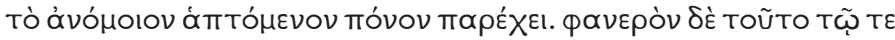

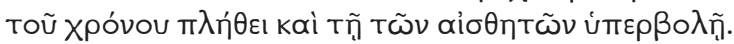

Anaxágoras pensa que a percepção é por contrários, pois o semelhante não é afetado pelo semelhante (...), uma coisa que é igualmente quente ou fria nem esquenta, nem esfria, e nem mesmo reconhecer o doce ou o acre pelos seus semelhantes, mas é pelo calor que reconhecemos o frio e pelo salgado, o bebível, o doce pelo amargo, em função da deficiência de cada um. Todas as percepções são acompanhadas de dor, pois diz que tudo já está presente em nós (...) e tudo que não é semelhante produz dor; e a presença dessa dor torna-se clara, ou por uma duração muito longa ou por um excesso de sensação.

A quantidade dos quatro humores varia de acordo com a oscilação no ambiente desses estados físicos. Afirma o médico tratadista do Da natureza do homem (7) que o fleuma, frio e úmido, predomina no inverno; o sangue, quente e úmido, na primavera; a bile amarela, quente e seca, no verão; e a bile negra, fria e seca, no outono. 
Assim, a saúde e a doença manifestam-se respectivamente pelo equilíbrio e o desequilíbrio dos elementos que configuram o corpo humano, principalmente os humores. O equilíbrio pode ser conservado ou recuperado mediante as relações entre a alimentação e a ginástica, elementos que formam uma equação baseada no tratamento pelos contrários: enquanto a alimentação preenche, o exercício físico esvazia, assim como as ações catárticas. Assim, prescritos com discernimento, os alimentos, liquefeitos no estômago e absorvidos pelos vasos, compensam a carência ou o excesso dos humores no corpo.

Os alimentos e as bebidas desempenham o papel de conservar ou de restituir saúde, e, para isso, é preciso conhecer suas propriedades. Apenas um bom conhecimento dessas propriedades permitirá suprir as carências ou evitar os excessos responsáveis pelo desequilíbrio. A partir da teoria humoral, que perpassa toda a medicina antiga, ainda que com diferentes codificações, os médicos buscam nos alimentos e nas bebidas as mesmas características do que as reveladas pela bile negra (seco e frio), pela bile amarela (seco e quente), pelo fleuma (úmido e frio) e pelo sangue (úmido e quente).

As propriedades fundamentais dos alimentos acompanham essas qualidades e dividem-se, geralmente, em quatro classes, em que o seco, o úmido, o quente, o frio apresentam intensidades diferentes, podendo ser combinadas de acordo com a finalidade. Contudo, não basta conhecer as propriedades naturais dos alimentos, pois elas se mostram instáveis, podendo

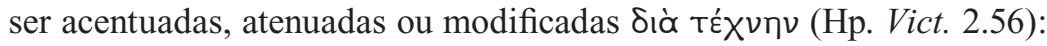

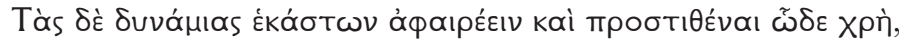

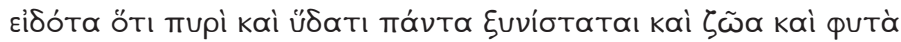

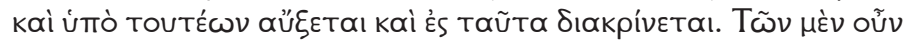

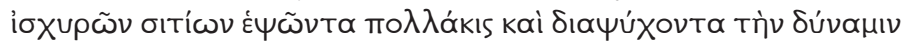

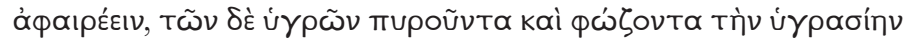

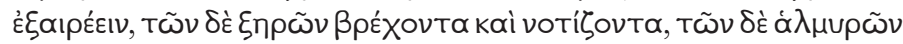

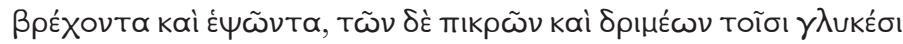

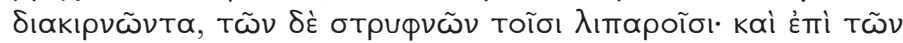

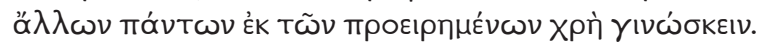

É preciso, pois, subtrair e acrescentar as propriedades de cada um do seguinte modo, sabendo que todas as coisas, tanto animais quanto vegetais, são compostas de fogo e água e que sob a ação deles se desenvolvem e neles se dissolvem. Os alimentos fortes, fervendo-os muitas vezes e resfriando-os, se lhes retira a propriedade; os úmidos, pondo-os ao fogo e grelhando-os, se lhes consome a umidade; os secos, embebendo-os e molhando-os; os salgados, embebendo-os e 
fervendo-os; os amargos e picantes, misturando-os com os doces, e os adstringentes com os gordurosos; e todas as coisas deve-se conhecêlas a partir do que já foi dito.

A doutrina de Anaxágoras pode ser percebida claramente no tratado Da dieta, não só pela concepção dos contrários, mas aparece visível numa estrutura do capítulo 4 do tratado, visível decalque do fragmento do filósofo de Clazómenas:

Da Dieta $1.4-$

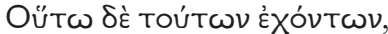

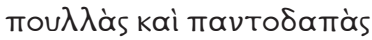

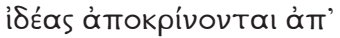

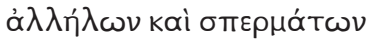

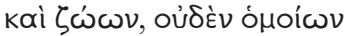

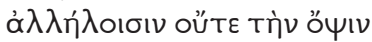

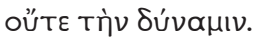

Anaxag. Fr. 4 DK -

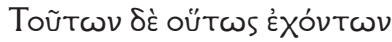

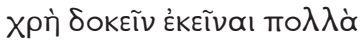

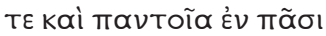

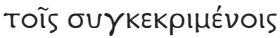

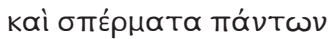

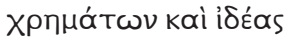
таvтоías हैXovta kai xpoiàs kaì ị́ovós.
Sendo assim essas coisas, separam-se elas entre si de muitas e de variadas formas tanto sementes quanto animais, em nada semelhantes entre si, nem em aparência, nem em propriedade.

Sendo essas coisas dessa maneira, é necessário considerar que elas, de muitas e de variadas (formas), em todas as combinações, são sementes de todas as coisas, tendo aparências, cores e qualidades sensíveis variadas.

Numa postura um tanto diversa à de Anaxágoras, mas que mesmo assim deixa entrever algumas ideias do filósofo, o autor do Da natureza do homem diz (9):

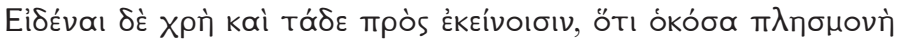

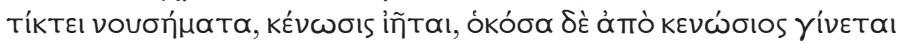

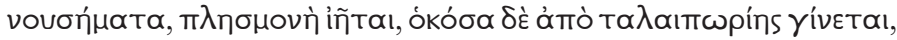

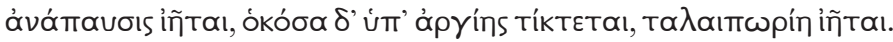

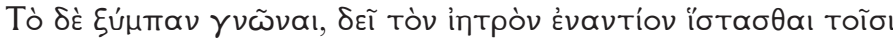

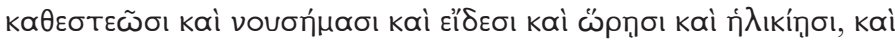

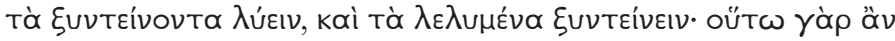

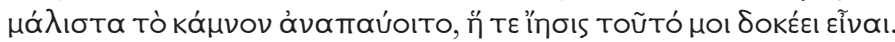

Além daquelas coisas, é preciso saber também destas: que as doenças que a repleção engendra, a evacuação as cura; as doenças que surgem 
pela evacuação, a repleção as cura; as que são oriundas do exercício, a pausa cura, e as que são geradas pela inércia, cura-as o exercício. Para resumir: o médico deve pôr-se em oposição às constituições das doenças, às características físicas, às estações e às idades, e relaxar o que estiver tenso, e retesar o que estiver relaxado. Pois, assim, o sofrimento cessaria de fato, e parece-me ser isto a cura.

O autor do Da dieta, considera fundamental a tensão e complementação entre os opostos, cujo maior exemplo talvez seja a dicotomia formada por vónos e qúoıs, que remete a um argumento presumivelmente retórico de uma oposição entre humano e divino (1.11):

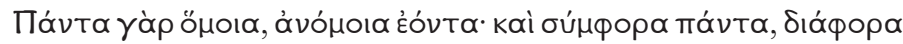

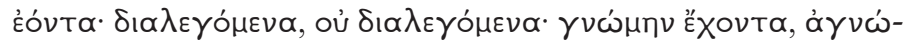

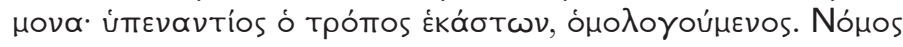

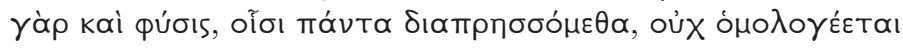

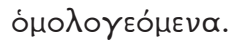

Pois tudo é semelhante sendo dissemelhante, concorda não concordando, possui razão, não tendo razão. Oposta é a direção de cada uma das coisas, completando-se entre si. Pois vónos e qúoıs, através dos quais obtemos tudo, não concordam concordando.

O saber médico, fundamentado por uma TÉx

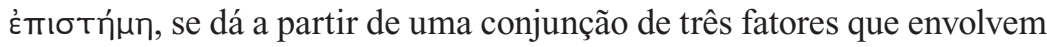

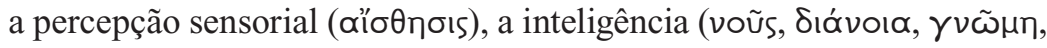

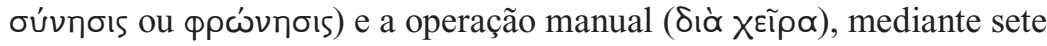

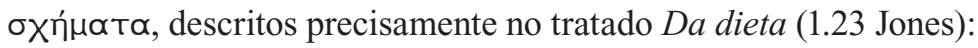

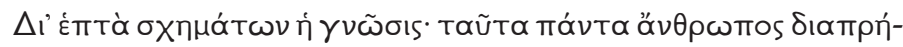

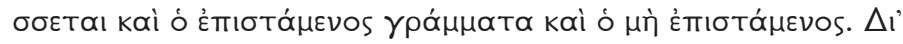

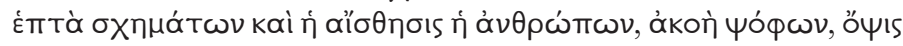

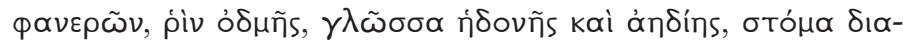

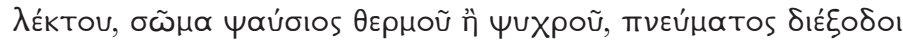

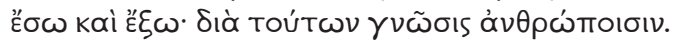

Através de sete figuras [se dá] o conhecimento: todos esses o homem obtém, tanto o que conhece a escrita quanto o que não conhece. A partir de sete figuras também [se dá] a sensação dos homens: o ouvido em contato com os sons, a vista com o visível, o nariz com o cheiro, a língua com o sabor do gostoso e do desagradável, a boca com a fala, o corpo com o tato, os condutos interiores e exteriores com o ar frio ou quente. Através delas, há conhecimento para o homem. 
No Da medicina antiga, essa relação é explicitada quando se pro-

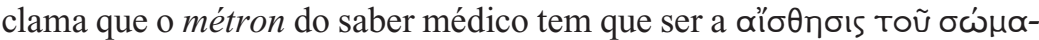
ToS, "sensação do corpo" do paciente (Hp. VM 9 Littré), o que se revela

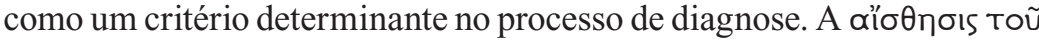

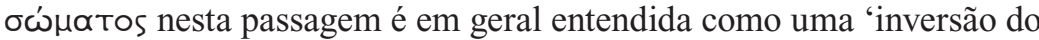
conceito de aïoӨnoıs que é liberado do estigma de subjetividade e convertido em critério científico objetivo ${ }^{28}$, o que poderia ser entendido como indício de um 'desapassivamento’ do sentir, em detrimento da concepção

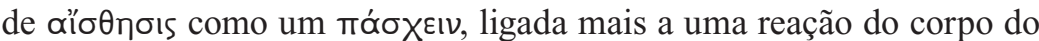
paciente (aos alimentos ou mesmo às sensações, como propõe Anaxágo-

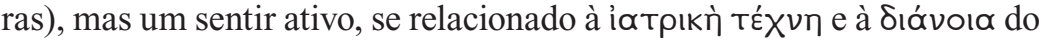
médico para detectar as doenças.

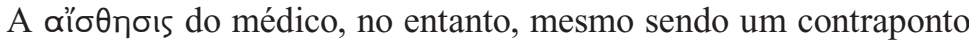
da oúvnoıs no processo de aquisição do conhecimento, diz respeito a um campo de ação empírica, combinando-se ao trabalho do intelecto, e revela-

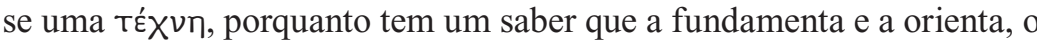

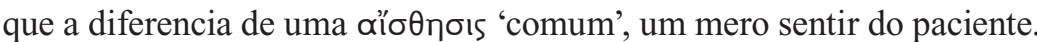

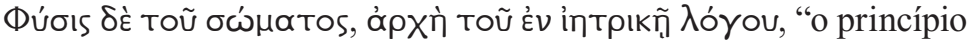

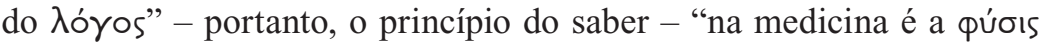
do corpo", diz o tratado Sobre os lugares do homem (2.1 Jones). O conhecimento da фúoıs do corpo é dado sobretudo através da observação

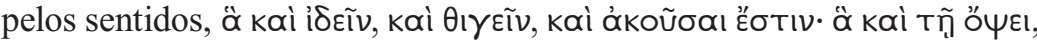

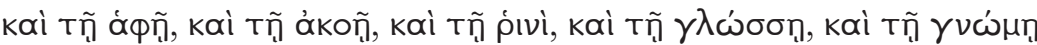

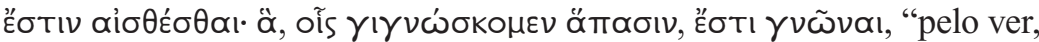
pelo tocar e pelo ouvir; o que se percebe com a vista, com o tato, com o ouvido, o nariz, a língua e o entendimento; o que se pode conhecer com tudo aquilo através do que se conhece", de acordo com o tratado Sobre o ofício do médico (1. 2-5 Jones).

Aristóteles, no início da sua Metafísica (980a.21-27), nos lembra que

ПávT

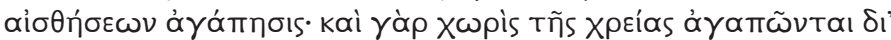

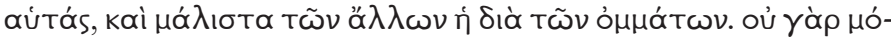

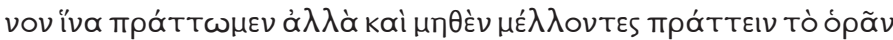

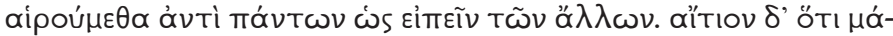

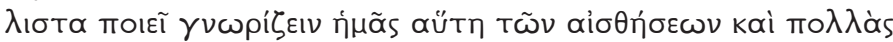

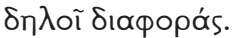

${ }^{28}$ H. Diller, Hippokratische Medizin und attische Philosophie, Hermes 80, 385-409, 1952 (apud MARK J. SchiEfSKy, Hippocrates. On ancient medicine, Leiden, Brill, 2005, p. 47). 
Todos os homens têm por natureza fome de saber. Sinal disto é seu gosto pelas sensações, pois estas, além do proveito que possam ter, agradam por si mesmas, e as da visão mais que as outras. Pois, não só em nossos afazeres, mas também quando não fazemos nada, preferimos o ver, por assim dizer, a todos os demais sentidos. E isso porque pela visão as coisas nos são mais notórias e manifestam muitas diferenças.

Essa passagem reflete o que, de resto, parece ser uma postura bastante comum entre os autores da Grécia clássica. Aqui vale referir o episódio narrado por Heródoto no livro I da História, o de Giges ante o pedido do soberano Candaules de ver a rainha da Lídia, sua mulher, nua, para que acreditasse que era ela a mulher mais bela de todas. A propósito desse projeto de Candaules, Heródoto (1.8.3) cita o adágio, segundo o qual

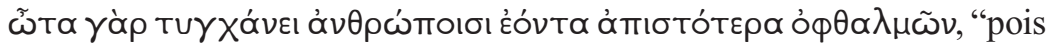
acontece de serem para os homens os ouvidos menos confiáveis do que os olhos". Heráclito, citado por Políbio (12.27), corrobora esse dito (Fr.

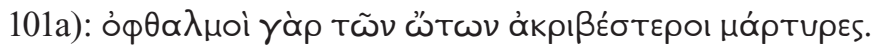

Essa especial atenção ao sentido da vista é também salientada em não poucos tratados do Corpus hippocraticum, pois é através da observação que o médico pode recolher dados importantes quanto aos sintomas ou oń $\propto$ đTa mais ou menos significativos que o paciente possa ou não apresentar, tais como a aparência da pele, das mucosas e dos olhos, ou o estado das secreções e excreções, os movimentos do corpo tais como tremores, calafrios, espasmos, convulsões etc. Em Predições II (10.14 Littré), para explorar as consequências de desordens dietéticas, o médico deveria examinar o paciente na mesma hora todo dia, no mesmo lugar e de preferência ao nascer do sol, porque, segundo o médico tratadista, 'é sobretudo a esta hora que o examinador tem os olhos mais penetrantes'. Desse modo, discernia os oń $\alpha$ т $\alpha$ da doença segundo o que ele julgava

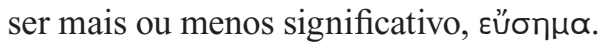

Através do tato era possível conhecer a temperatura, a consistência do ventre, a pulsação, o volume e as vultosidades tumorais etc; assim como, através do olfato, podia-se perceber o cheiro da pele, da boca, das fezes, da urina e assim por diante; pela audição, conhecia-se a respiração, a tosse, a voz do doente, etc. Dessa forma, por meio desses sentidos, o médico podia localizar e formular os ơ $\delta \eta \lambda \propto$, aquilo que não é evidente aos sentidos.

O tratado Da arte apresenta, assim, a postura do médico diante da

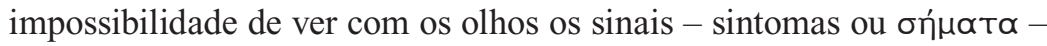




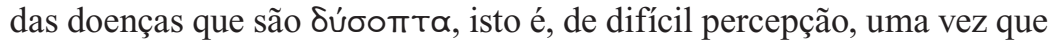
não existe doença que não apresente sinais, e recorre, mais uma vez, ao exame minucioso através das funções congitivas dos outros sentidos, justificando (11.1-12 Jones):

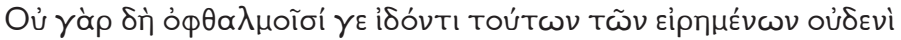

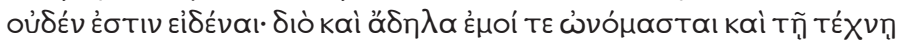

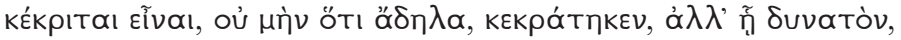

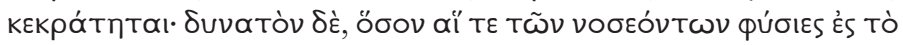

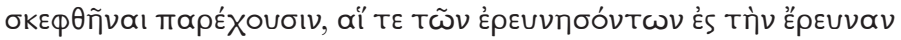

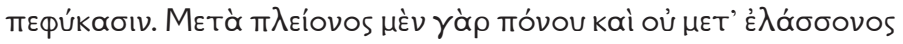

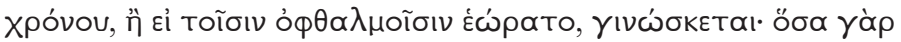

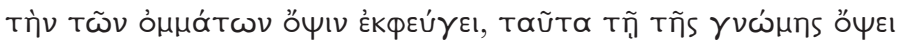

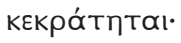

Pois certamente nenhuma das coisas ditas se pode conhecer por vê-las com os olhos; portanto, eu mesmo chamei de invisíveis estas coisas e assim foram julgadas pela TÉ X $\vee \eta$, não que por serem invisíveis fossem dominantes, mas foram submetidas até onde foi possível. É possível, na medida em que as naturezas dos doentes admitam serem examinadas e as dos que investigam tenham a disposição de serem investigadas. Pois se com os olhos as víssemos, as conheceríamos só depois de muito esforço e de muito tempo; uma vez que as coisas que fogem ao exame dos olhos são submetidas ao exame através da inteligência.

Mas a atenção do médico não é direcionada apenas aos sinais do

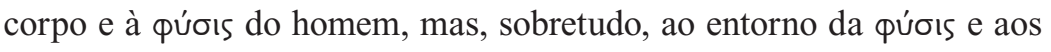
hábitos ligados a este entorno, uma vez que o meio age no vónos como um fator determinante e delimitador, de acordo com os preceitos do tratadista de Dos ares, águas e lugares, que mais adiante serão retomados pelo autor do Da dieta, tratado que, no mais, apresenta elementos na narrativa que confirmam uma herança dessa tradição de escrita.

O médico tratadista do Da dieta insiste na preocupação de conhecer

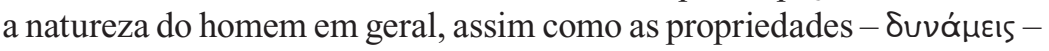
e composição de cada alimento e a sua adequação aos costumes e entorno do indivíduo, pois disso depende a manutenção ou recuperação da saúde e disso depende também o conhecimento e a prática do médico diante da doença (1.2 Jones):

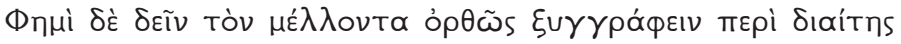

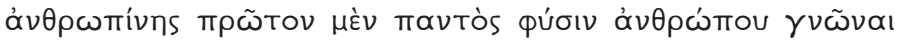

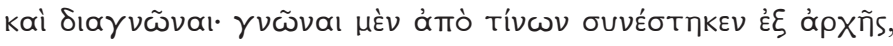




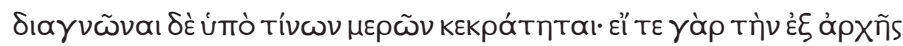

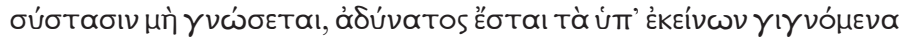

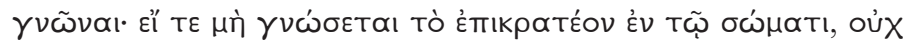

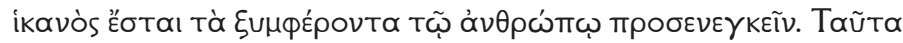

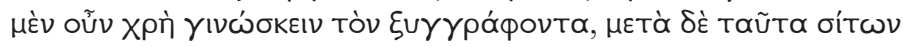

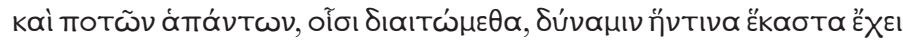

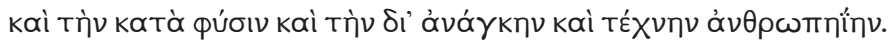

Afirmo que para compor um escrito acertadamente sobre a dieta, é preciso antes que nada conhecer e discernir a natureza do homem por inteiro: conhecer a composição de cada parte desde o princípio, discernir por quais partes está governado; porque se não se conhecer a composição elementar, será impossível saber o que vem a ser a partir deles. Além disso, se não se conhece o que governa no corpo, não será capaz de procurar o que é apropriado para o homem. Estas coisas, portanto, quem escreve precisa conhecer, e além disso, de todos os alimentos e bebidas com os quais nos alimentamos, precisa conhecer a propriedade que cada um possui, sejam eles naturais, sejam eles por necessidade manipulados pelo homem.

A proximidade desse parágrafo com a famosa passagem do Fedro em alusão ao método hipocrático quando se investiga acerca do conhecimento da alma (Pl. Phdr. 270c-d), foi e ainda é objeto de múltiplas atenções, porquanto a intervenção do médico que tem por fundamento

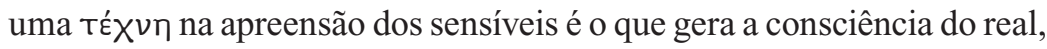

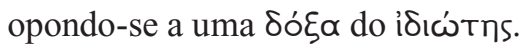

O interrogar o doente é componente essencial do diagnóstico médico, uma vez que, por esse meio, conhecia-se sua maneira de viver e seu modo de sentir a doença. Entretanto, o paciente nunca terá a precisão e o rigor do médico, nem mesmo esse olhar direcionado que é próprio de

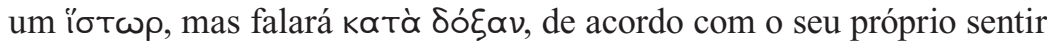
e a sua própria opinião. $\mathrm{O}$ Da dieta traz a seguinte assertiva acerca desse

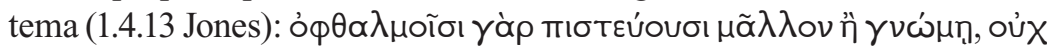

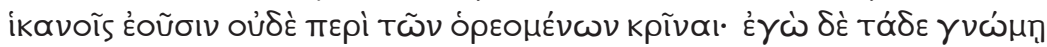

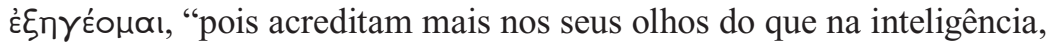
não sendo capazes de discernir nada dentre as coisas visíveis. Eu, no entanto, estas coisas explico a partir da inteligência - $\gamma \nu \omega \dot{\mu \eta \eta}$-." E ainda sobre esse assunto, o tratadista de Da arte (11.12 -18) diz:

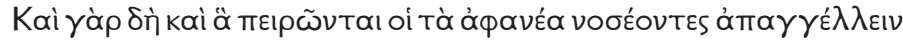

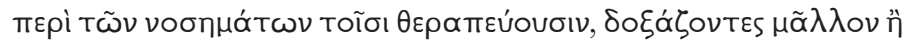
Ei்ót 


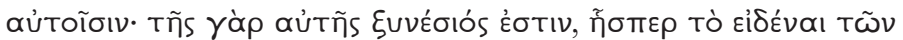

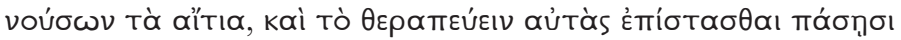

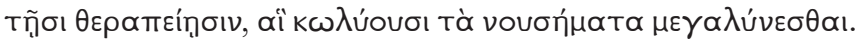

Porque, certamente, o que os que sofrem de doenças não aparentes relatam acerca das suas doenças àqueles que os tratam, relatam opinando mais do que sabem; pois se conhecessem, não teriam caido nelas; pois é próprio da inteligência o conhecer a causa das doenças e o tratá-las conhecendo todos os tratamentos que as impedem de aumentar.

O sentir e o curar são dois aspectos fundamentais da consciência do médico, que é também o grande diferencial entre o i̊rpós e o íıı́tms, e é essa mesma consciência a delimitadora e configuradora do campo de prática e de conhecimento da medicina hipocrática e do lugar social do médico.

A partir do século XIX, com a descoberta do manuscrito Anônimo de Londres, que continha uma diminuta parte da 'enciclopédia' do Liceu aristotélico - provavelmente de autoria de um discípulo direto de Aristóteles, Mênon -, foi possível lançar luzes sobre as ideias médicas de pensadores que até então não tinham sido relacionados com essa temática. Dentre estes, vale destacar Hípon de Samos e Filolau de Crotona, ambos fortemente influenciados por Pitágoras. O primeiro, monista, possivelmente influenciado por Tales ${ }^{29}$. De acordo com Anônimo de Londres (11.12),

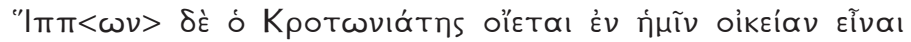

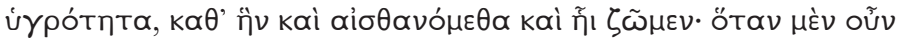

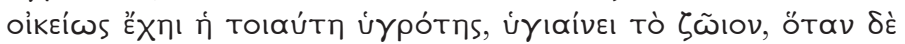

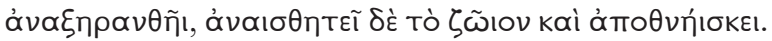

Hípon, o crotoniense, opina que existe em nós uma umidade natural, através da qual sentimos e por meio da qual vivemos. Quando essa umidade existe, o animal vive, mas quando essa umidade é consumida, o animal morre.

A concepção de Hípon de Crotona está bastante afinada com a ideia hipocrática de que vida está ligada à presença do úmido. Tal convergência pode levantar alguma hipótese de influência, mas ainda é pouco para confirmá-la, mas pode ser percebida no capítulo 56 do Da dieta: Tòs $\delta$ غ̀

${ }^{29}$ É o que parece denunciar o lugar central que ocupa a água em seu pensamento. Ver Daniel Delatre, 'Les pythagoriciens rédents' in Jean-Paul Dumont (ed.), Les présocratiques, Paris, Gallimard, 1988. p. 1341. 


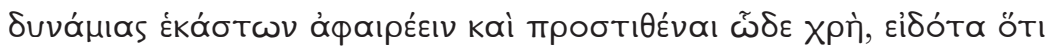

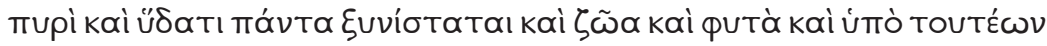

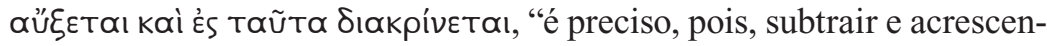
tar as propriedades de cada um do seguinte modo, sabendo que todas as coisas, tanto animais quanto vegetais, são compostas de fogo e água e que sob a ação deles se desenvolvem e neles se dissolvem." E, ainda, tà

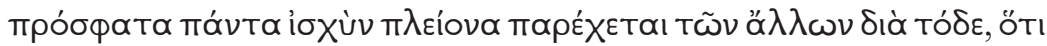

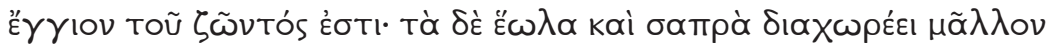

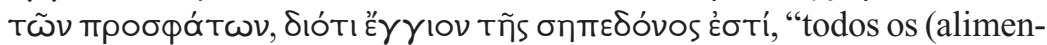
tos) frescos fornecem mais força do que os outros, por isto, porque estão mais próximos do que está vivo. Os velhos e pútridos são mais laxantes do que os frescos, porque mais próximos da corrupção."

Outro filósofo nomeado pelo Anônimo de Londres é, como já dito, Filolau de Crotona, cujas ideias médicas podiam ser, até então, quando muito, supostas. A partir desse testemunho, conhece-se o seu interesse por questões relacionadas à fisiologia e à medicina, num escrito de embriologia, ao estilo da tradição dos escritos médicos. Segundo o texto (Anon. Lond. $18.8=$ Philol. Fr. 27 DK):

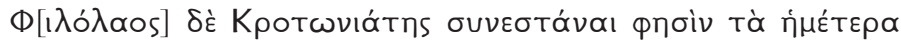

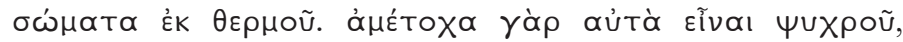

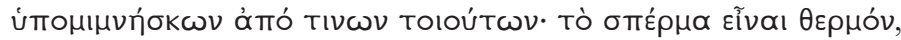

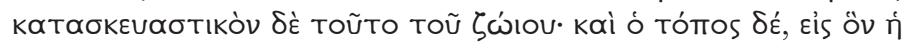

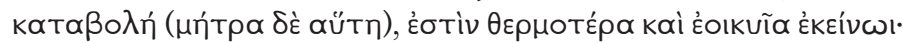

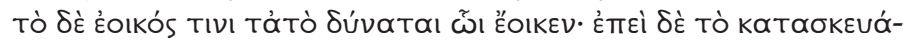

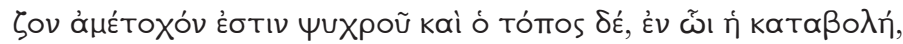
ǻ

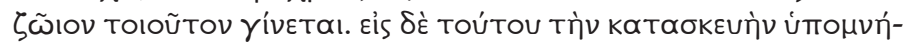

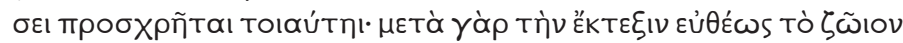

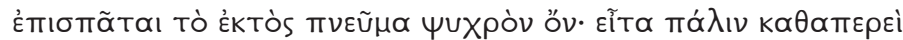

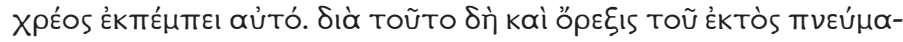

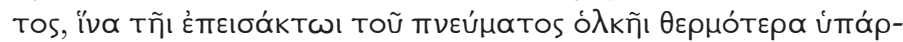

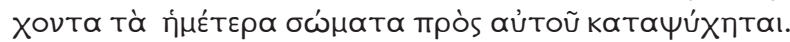

Filolau o Crotoniense diz que os corpos se compõem do quente, pois eles não participam do frio, sendo este o seu raciocínio a partir de considerações como as seguintes: o esperma é quente, e é o esperma que produz a coisa viva, e o lugar em que ele é depositado é, como ele, quente; e aquilo que é semelhante a alguma coisa tem o mesmo poder que aquilo a que se assemelha. Visto que, portanto, o fator produtivo não participa no frio, e que, também, o lugar em que é depositado não participa do frio, é claro que a coisa viva produzida também há de ser da mesma natureza. Imediatamente após o nascimento, a coisa viva 
inspira o ar do exterior, que é frio; e então por necessidade, expele-o de novo. Este desejo do ar exterior surge, para que, como resultado da inalação do ar, nossos corpos, que por natureza são demasiado quentes, possam ser refrescados por ele.

Em postura análoga, o capítulo 10 do tratado $\mathrm{Da}$ dieta afirma, quando se refere à geração do embrião, que são as mesmas variáveis que incidem sobre o feto:

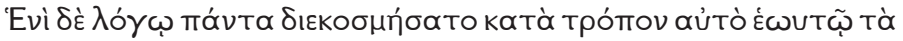

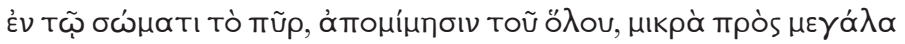

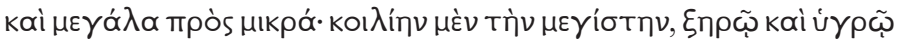

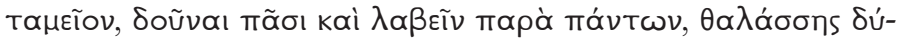

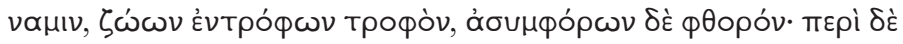

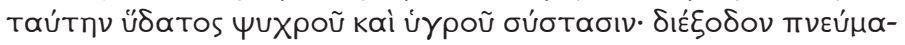

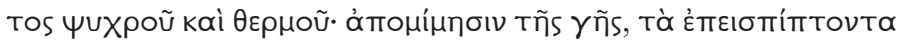

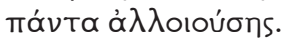

Em uma palavra, o fogo deu ordem, da maneira que lhe é própria, àquilo que está no interior do corpo, uma imitação do universo, o que é pequeno em relação ao que é grande e o que é grande em relação ao que é pequeno; sendo o ventre o maior (dos órgãos), receptáculo do seco e do úmido, fornece a todos e recebe de todos (os órgãos), (tem) a propriedade do mar, alimentador dos animais que servem de alimento e destruidor dos inúteis. Em torno dele, há uma condensação da água fria e úmida; passagem do ar frio e quente; imitação da terra, que transforma todas as coisas que caem (sobre ela).

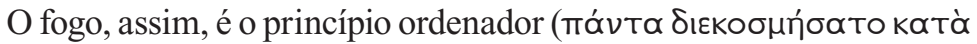

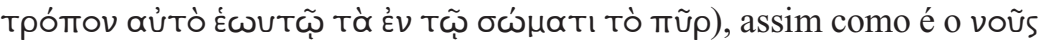

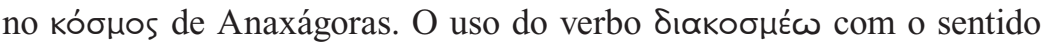
do "organizar", "ordenar" anuncia a comparação do microcosmos e do macrocosmos. O amplo comentário de R. Joly ${ }^{30}$ a essa passagem atribui tal concepção não a doutrinas orientais, como sugerem Götze e Kranz ${ }^{31}$, mas tende a considerar tal perspectiva como influência dos pitagóricos.

Entre pré-socráticos, médicos (das escolas de Cós e de Cnido) e historiadores, o tratado Da dieta inscreve-se no trânsito de saberes e nos jogos discursivos de seu tempo. Essa inserção ganha especial relevo quando lembramos da importância desse tratado na história do pensa-

${ }^{30}$ Recherches sur le traité pseudo-hippocratique Du regime, Paris, Les Belles Lettres, 1960 , p. $35-75$.

${ }^{31}$ Apud Joly, 1960, p. 37-9. 
mento médico, como um dos textos que assinalam com maior clareza a identidade da chamada escola de Cós. Não há dúvidas de que, para essa vertente do pensamento médico da época, a dieta - compreendida em toda a sua extensão - era o principal instrumento, secundado pelo фápưкov,

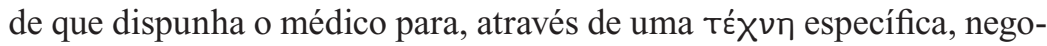
ciar com a qúoıs em prol da sanidade. Essa negociação passava neces-

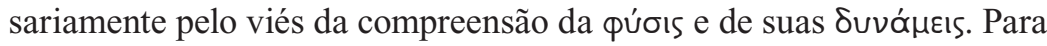
compreendê-las e para discuti-las, tentamos aqui apontar que foi preciso lançar mão de estratégias discursivas que integravam um projeto - que resultou vitorioso - de legitimação de um campo e que não podiam deixar de, tal qual os heraclíticos arco e lira, transigir com as ideias entre as quais havia que transitar.

TitLe. Nutrition in Hippocratic diet.

ABstract. This paper examines the relations among the treaty On diet, from the Corpus hippocraticum, and some discourses and ideas coeval with it, this work aims to present the treaty's intense insertion in the discursive games and in the flow of ideas that surronded it. Starting with a presentation of the treaty and the highlighting of its extensive excerpt dedicated to feeding, this paper goes through its intertextual bonds. KEYWORDS. Hippocratic diet, corpus hippocraticum, medicine in Antiquity, nutrition in Classical Antiquity, ancient science. 